What causes autism?

\title{
㧓独谱系障碍病因研究的现况
}

郑毅

首都医科大学附属北京安定医院, 北京 100088

E-mail: doctorzy@yahoo.com

2015-10-28 收稿, 2015-12-22 修回, 2015-12-23 接受, 2016-01-22 网络版发表

北京市医管局重点医学专业发展计划(ZYLX201403)资助

摘要探索孤独谱系障碍(ASD)的病因是国内外科学研究的热点, 每年全球大量的人力和资金投入其中, 但收 效甚微, 未见到突破性的发现, 而且有些结论相互矛盾, 缺少单一性和特异性的结果. 其实, 不难发现, 目前研究 的误区较多, 临床和基础研究脱节, 表型与基因型不符, 单一疾病还是复合障碍没弄清楚, 已严重影响了我国的 ASD病因研究. 因此, 精准临床表型、严格分类和诊断、避免盲目和重复的研究是当务之急. 走出误区, 联合攻关 是方向.

关键词孤独谱系障碍, 病因研究, 临床表型

孤独谱系障碍(autism spectrum disorder, ASD) 是 指以社会交往困难, 语言交流障碍和兴趣范围狭窄 及刻板行为为主要临床表现的一组神经发育障碍. 2013 美国最新诊断与分类标准明确了这一诊断 ${ }^{[1,2]}$, 包含了既往 4 种广泛性发育障碍, 即孤独症(亦称自 闭症 (Autism Disorder, AD)、阿斯伯格综合征 (Asperg's Syndrome, AS)、童年瓦解症(Heller's Disease, HD) 和未特定的广泛性发育障碍 (pervasive developmental disorder not otherwise specified, PDDNOS), 其患病率高达0.1\% 1\% ${ }^{[3,4]}$, 终身影响和社会 负担之重已经引起广泛重视和重点研究.

显然, 目前的定义和分类仍然是基于临床症状 而非病因. 这些疾病由典型的孤独症到非典型的、未 特定的广泛性发育障碍组成了一个连续谱, ASD 是这 一系列疾病的总称. 但是人们追求病因清楚的理想 分类始终没有停止. 任何疾病, 研究人员都想找到病 因, 寻求治疗和预防的方法, 以减少人类的痛苦. 对 ASD也是如此. 然而至今, 除了雷特综合征(Rett Syndrome) 找到 $M E C P 2$ 基因的病因以及和部分儿童瓦解
症是中枢神经退化症的表现之外, 全世界的研究仍 在继续努力找寻 $\mathrm{ASD}$ 的病因. 目前, 事实证实 $\mathrm{ASD}$ 并 不是单一疾病, 就像雷特综合征找到病因后从ASD家 族分离一样, 随着医学的进步, 将会有一个一个的疾 病病因被研究清楚而按病因分类, 甚至归属到神经科 或其他科.

\section{1 艰难的病因探索之路}

目前 $\mathrm{ASD}$ 的病因未明, 文献报道中 ASD与孤独 症的研究也未有明确区分. 经过半个多世纪的研究, 各种证据支持ASD是由多种生物学因素和环境因素 所致的神经发育障碍, 近年来研究主要集中在遗传、 神经影像、神经生理和生化、神经心理、社会环境以 及早期发育中的危险因素等方面 ${ }^{[4]}$. 每年全球大量的 人力和资金投人到该病病因研究之中.

当前单一因素很难解释孤独症的多种症状, 普 遍认为孤独症与早期发育中的危险因素、遗传因素、 脑部发育异常都可能存在关联. 多数研究者认为孤 独症不是单个基因异常所致，而可能是涉及3 15个

引用格式: 郑毅. 孤独谱系障碍病因研究的现况. 科学通报, 2016, 61: 677-681

Zheng Y. Comments of the current study on the etiology of autism spectrum disorders (in Chinese). Chin Sci Bull, 2016, 61: 677-681, doi: 10.1360/N972015-01210 
基因的多基因遗传性病症, 同时易感基因并不一定 是引起孤独症的直接原因, 孤独症的发病可能是在 多种因素的作用下, 带有遗传易感性的个体产生基 因突变所致 ${ }^{[5]}$.

\section{1 遗传因素}

多年的研究表明, ASD是高度可遗传的, 其家族 聚集性已经在遗传学研究中被证实, ASD在同卵双生 子中同病率更高达60\% 90\%, 双卵双生子同病率为 10\%, 约 2\% 14\%的同胞和其他家庭成员也患有这种 障碍, 比普通人群高出10 20倍.

分子遗传学的研究揭示, ASD的易感基因涉及多 个基因, 其中位于第 7 对染色体 7q22/3132的Wnt2 和 HoxAl 基因在调控胎儿早期大脑发育或细胞分化过 程中起关键作用, 血清素转运基因(5-hydroxytamine transporter, 5-HTT) 和位于第 15号染色体上 15q11-13 的GABRB (gamma-aminobutyric acid receptor beta)基 因与维持正常脑功能的某些中枢神经递质有关. 这 些基因突变可能导致胎儿大脑发育异常, 从而引发 $\mathrm{ASD}$; 通过相关分析及与对照组的差异, 由家族有多 人罹患 $\mathrm{ASD}$, 尤其亲子二代有 3 人罹病的 trios来分析 某些疑似基因和 ASD的相关性. 但是这种研究方法 由于 $\mathrm{ASD}$ 表型本身的异质性受到了限制. 迄今为止, 经过几次国际范围内的分子遗传学篮查, 在多条染 色体上都发现了至少一处孤独症相关的位点, 并且 热门研究区域集中位于 $X, 2,3,7,15,17$ 和 22 号染色 体上. 显然, 表型对基因型研究影响巨大 ${ }^{[6]}$.

\section{2 环境因素}

尽管ASD主要的病因被认为是遗传因素, 但是 环境因素也能影响表型, 从而影响病情, 特别是那些 在胎儿大脑发育关键期接触的环境因素可能会影响 基因的表达. 有研究显示, 父方或母方的年龄与孩子 患 ASD的风险相关, 年龄越大孩子患病的比例越高, 这可能是由基因突变的积累和基因印迹造成的. 在 怀孕早期接触中枢神经系统致畸剂也会导致ASD发 病可能性增加 ${ }^{[7]}$. 一些研究还暗示某些表观遗传机制 和外显子异常可能与ASD有关. 目前, 研究主要集 中在以下几方面.

(i ) 脑器质性因素. 大量的磁共振 (magnetic resonance imaging, MRI)、功能磁共振 (functional magnetic resonance imaging, fMRI)、正电子扫描 (positron emission tomography, PET)等研究显示, 孤 独症患者存在脑结构和功能的异常 ${ }^{[8]}$. 特别是基于面 孔和表情识别、情绪理解、社交手势等认知任务的功 能性磁共振研究显示, 孤独症患者存在颢上沟、梭状 回、杏仁核等功能异常. 因此, 有学者提出“社会脑” 的概念, 即与社会交往关系密切的脑区，包括前额叶 皮层中部、颞顶叶连接区、前扣带回、脑岛、杏仁核 等. 因社会脑功能发生异常, 个体难以综合处理社交 信息, 从而产生社会交往障碍. 尸解研究发现该障碍 患者颞中回、小脑、海马和杏仁核存在细胞学异常.

(ii) 神经生化因素. 既往有关五羟色胺(5-hydroxytamine, 5-HT) 的研究较多, 研究结果不一致. 有研究发现. 约 $1 / 3$ 孤独症患儿血5-HT水平增高, 但 这种现象也存在于患儿亲属中; 还有研究发现孤独 症患儿皮质和丘脑的5-HT合成减少, 孤独症患儿母 亲的血浆5-HT水平明显低于正常儿童母亲等. 目前, 基于动物实验的研究提示 5-HT与儿童脑发育关系密 切. 因此, 有学者认为, 发育早期血脑屏障发育不完 善, 血中高浓度的5-HT可通过血脑屏障进人脑, 经 脑内 5-HT的负反馈机制而作用于 5-HT神经元，影响 其生长, 从而造成儿童行为上的改变. 还有学者认 为, 母亲低血浆5-HT水平可能通过影响胎儿脑发育 而成为儿童孤独症的危险因素之一.

除5-HT外, 还有个别研究发现, 孤独症患儿脑 脊液中多巴胺 (dopamine, DA) 代谢产物高草香酸 (homovanillic acid, HVA)水平增高, 并与该障碍的多 动及刻板行为相关. 虽有部分关于孤独症儿童脑脊 液中 $\beta$-内啡肽水平的研究报道, 但研究结果不一致.

近几年, 因动物实验表明催产素在亲社会行为 中起着重要作用, 因此, 众多研究关注于催产素与儿 童孤独症之间的关系. 有研究显示, 孤独症患者与年 龄匹配的正常对照相比, 血浆催产素水平显著降低, 无活性的催产素前体与催产素的比值显著高于正常 对照. 还有研究报道给孤独症患者注射催产素, 催产 素注射组的重复行为较安慰剂组显著减少. 因此, 催 产素神经通路的异常可能与儿童孤独症相关.

（iii）感染与免疫因素. 已有研究表明, 孤独症 患儿存在免疫系统异常, 包括 $\mathrm{T}$ 淋巴细胞、辅助 $\mathrm{T}$ 细胞 和 $\mathrm{B}$ 淋巴细胞数量减少, 抑制-诱导 $\mathrm{T}$ 细胞缺乏, 自然 杀伤细胞活性降低; 补体 C4B蛋白水平明显降低; IL-12和INF- $\gamma$ 水平明显高于正常对照等. 另有研究报 道, 在孤独症患者中针对髓鞘蛋白、轴索蛋白和胶质 
纤维酸性蛋白的自身抗体的水平明显高于正常对照. 孤独症患儿还存在免疫基因的异常, 如 HLA-DR4基 因, $H L A-A 2$ 基因等. 因此, 有学者提出, 由于孤独症 患儿免疫系统存在异常, 因而易于发生病毒感染, 而 病毒诱导的自身免疫反应可能在儿童孤独症的发生 中发挥一定作用 ${ }^{[9]}$.

（iv）营养及脑肠循环. 目前的研究表明, 饮食 与自闭症关系密切, 不良的饮食习惯、食物中的有害 物质、对营养物质的吸收、利用和代谢异常, 可能影 响免疫、内分泌和能量代谢系统, 最终影响大脑的发 育. 维生素D、欧米伽 3 、欧米伽5在临床使用和机理 研究已经引起关注. 同时, 食物是肠道微生物的重要 影响因素, 而肠道微生物对人体健康至关重要, 且通 过微生物-肠道-脑轴 (microbiome-gut-brain axis, 菌肠 脑轴) 影响大脑. 饮食, 肠道微生物与 ASD的关系正 在成为当前的研究热点.

\section{3 神经心理机制}

近年来, 关于儿童孤独症神经心理机制的研究 日益增多. 目前引人关注的是心理理论缺陷理论、中 央信息整合缺陷理论、执行功能障碍理论. 心理理论 是指个体识别他人心理状态(如需要、信念、愿望、 意图、感知、知识、情绪等), 并由此对他人行为做 出因果性解释和预测的能力. 目前研究显示, 孤独症 患儿在心理理论能力方面存在缺陷, 从而影响其社 会交往. 孤独症患儿中央信息整合能力存在缺陷, 他 们擅长于处理信息局部特征, 而不善于处理整体和 关联信息, 从而难以从整体的角度观察、分析和理解 事物. 孤独症患儿存在执行功能的缺陷, 他们从一个 分类原则转换到另一个分类原则时存在困难, 抑制 控制能力弱、计划能力弱等. 虽然孤独症患儿存在上 述认知功能缺陷, 但是这些认知功能缺陷并非孤独 症患儿所特有, 其脑机制及其与孤独症症状的关系 也不明确.

显然, 许多研究者和临床专家从不同的层面向 ASD的病因、发病机制和临床表现的研究进军, 希望 对ASD提出有效的治疗和预防措施. 但是, 目前离理 想的病因诊断和治疗还相差甚远.

\section{ASD病因学研究中的误区}

近 5 年国家已经将许多项目都直接或间接投人到 了ASD相关的研究, 如国家重点基础研究发展计划、
国家高技术研究发展计划、国家公共卫生专项、国家 科技支撑计划、国家自然科学基金、推进创新神经技 术脑研究计划等项目投人经费，估计要以“亿”为单位 计算; 国家卫生和计划生育委员会颁布了“中国孤独 症诊疗康复指南”和“中国儿童心理保健技术规范”来 规范ASD的临床表型和规范化的诊断; 中国残疾人联 合会也积极推进全社会对ASD的关注，国家领导人和 社会公益人士也积极关心、推动ASD的研究和治疗.

但是, 客观地讲, 病因学研究收效甚微, 未见到 突破性的发现，而且有些发现相互矛盾. 有些发现可 以涉及多种疾病, 缺少单一性和特异性的结果. 其实, 不难发现, 目前研究的误区仍较多, 临床和基础研究 脱节; 表型与基因型不符; 单一疾病还是复合障碍没 弄清楚, 这些已严重地影响了我国的ASD病因研究.

\section{3 走出误区联合攻关}

回顾近些年国内的研究历程和纵观国际的研究 发展, 发挥各学科的优势联合攻关可谓是一条成功 之路.

\section{1 精准临床表型}

从根本上分析, ASD的临床表型确定就存在很多问 题. 寻找ASD的基因, 最大的困难是ASD的表型和基因 型的异质性. 目前基础研究条件和水平较高的研究单 位，临床力量不一定强大; 临床条件较好的医院，基础 研究不一定很强. 目前虽然多是采用基础与临床结合 的方式, 但是我国儿童精神科医师队伍薄弱, 又缺乏专 业医师的严格准人制度; 还有我国各地快速建立起来 的众多“自闭症康复中心”, 多数缺乏专业人士把关. 可 想而知临床病例无法做到标准化的问题必然非常严重.

其实, 国家已经颁布了“孤独症诊疗康复指南”, 较为准确的诊断, 临床表型的确定是可行的. 关键是 要强强联合, 开展专业机构的联合攻关.

\section{2 科学掌握疾病的分类和诊断}

最新的美国疾病诊断与分类手册明确了ASD的 概念, 是一组神经发育障碍. 因此, 探讨病因的研究 临床表型要准确, 研究应该尽量确定到亚型. 很显 然, $\mathrm{AS}$ 与 HD临床表型是不一样的, 病因应该有所不 同. 若临床样本混为一谈, 可想而知, 病因研究又怎 么能有个体化的发现呢? 显然, 在采用最新诊断标 准时要科学. 特别是病因学研究时更应该细化, 将亚 
型和功能进行细化和分析. 事实上, 目前 ASD与孤独 症概念混用, 许多智力发育障碍与孤独症诊断相混 淆. 例如, 20 世纪 80 年代之前, 孤独症很少见, 主要 诊断是精神发育迟滞; 而现在孤独症很普遍, 而精神 发育迟滞的诊断明显减少. 显然, 正确的疾病诊断和 分类直接影响病因学研究.

\section{3 科学决策避免盲目和重复}

目前多部门投人, 大量资金用于ASD病因学研
究是好事，但是有许多研究雷同和重复. 因此，国家 层面统筹资金和研究力量, 严格把关, 把好钢用到刀 刃上, ASD的病因研究一定能有所突破.

$\mathrm{ASD}$ 是神经发育障碍中最具代表性的疾病, 其 病因学的突破不但能为临床诊断和治疗提供科学的 依据, 促进疗效, 攻克这一顽症; 对脑功能的研究和 相关疾病的研究提供科学的模式和基础. 让研究者 们共同努力，期待着ASD病医学研究的突破，期待着 人类战胜 $\mathrm{ASD}$ 这一天的到来!

\section{参考文献}

1 American Psychiatric Association (APA). Dignostic and Statistical Manual of Mental Disorders. Fifth Edition. (DSM-5). Alingdon: American Psychiatric Association Publishing, 2013. 31-86

2 Zheng Y. Commentary: The new diagnosis and classification of child mental disorders-reflections on Rutter. J Child Psychol Psy, 2011, 52: $677-668$

3 Zheng Y, Zheng X X. Current state and recent developments of child psychiatry in China. Child Adoles Psy Ment Health, 2015, 9: 2-10

4 US-CDC. Center for disease control and prevention: Prevalence of autism spectrum disorders-autism and development disabilities monitoring network, 14 Sites, USA, 2008, 61: 1-19

5 Zheng Y. The mental disorders usually occurring in childhood and adolescence. In: Jiang Z F, Shen K L, Shen Y, eds. Zhu Futang Practical of Pediatrics (8th Ed). Beijing: People's Medical Publishing House, 2015 [郑毅. 儿童和青少年期常见的心理障碍. 见: 江载芳, 申昆玲, 沈颖, 主编. 诸福棠实用儿科学, 第 8 版. 北京: 人民卫生出版社, 2015]

6 Warrier V, Chee V, Smith P, et al. A comprehensive meta-analysis of common genetic variants in autism spectrum conditions. Mol Autism, 2015, 6: 49

7 Rossignol D A, Genuis S J, Frye R E. Environmental toxicants and autism spectrum disorders: A systematic review. Trans1 Psychiat, 2014, 4: e360

8 Bos D J, van Raalten T R, Oranje B, et al. Developmental differences in higher-order resting-state networks in Autism Spectrum Disorder. NeuroImage Clinlin, 2014, 4: 820-827

9 Wu S Q, Ding Y Y, Wu F Q, et al. Family history of autoimmune diseases is associated with an increased risk of autism in children: A systematic review and meta-analysis. Neurosci Biobehav Rev, 2015, 55: 322-332

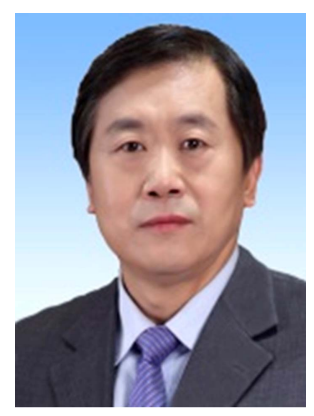

\section{郑毅}

主任医师, 教授, 博士生导师。北京安定医院副院长. 国际儿童青少年精神 医学及相关学科协会副主席. 中国杰出精神科医师; 国际儿童青少年精神医 学突出贡献奖获得者. 曾主持国家“十二五”科技支撑计划、国家和北京市自 然基金、北京市科委科研专项等重大项目, 研究重点为儿童神经精神发育障 碍的病因、诊疗和预防. 负责制定国家《孤独症诊疗康复指南》等多部行业 指南和规范. 


\title{
Comments of the current study on the etiology of autism spectrum disorders
}

\author{
ZHENG Yi
}

Beijing Anding Hospital, Capital Medical University, Beijing 100088, China

Autism spectrum disorder (ASD) was proposed in the Diagnostic and Statistical Manual of Mental Disorders version 5 (DSM-5), released May 2013. The new diagnosis encompasses previous diagnoses of autistic disorder, Asperger's syndrome, childhood disintegrative disorder, and pervasive developmental disorder not otherwise specified (PDD-NOS). So ASD is a group of developmental disabilities that can cause significant social, communication and behavioral challenges. To estimate a prevalence is $0.1 \%-1 \%$. The importance of lifelong influence and social burden has attracted extensive attention and focus of research. Searching for the cause of ASD is the hotspot of medical study in China and all of the world recently.

Many etiologic researches focus on genetics, brain imaging, nerve biochemistry, infection and immunity, nutrition and intestinal cerebral circulation, and neuropsychology. Obviously, many researchers and clinical experts explore the etiology of ASD from different levels and different point of view on the pathogenesis and clinical manifestation of ASD and aim to put forward effective prevention and treatment of ASD. However, it is also far away from making the etiological diagnosis and treatment of ASD. Although there were a large number of scholars and the influx of funds, a little success was achieved. There is no breakthrough discovery, and some results have been found conflicting. Especially it is lack of distinctive and specific results.

In fact, it is obvious that the some current researches were fallen in many misunderstandings, the separation of clinical and basic research; no match in phenotype and genotype; no clear for single disease or composite disorders. These have seriously affected etiological research. From the fundamental analysis, the search for ASD, the biggest difficulty is the heterogeneity of the phenotype and genotype of ASD. There are many problems to determine the ASD phenotype. Most of power basic research groups are not necessarily strong in clinical diagnosis and evaluation and in contrast some power clinical research units are not relatively good in basic research. Although it is the use of both basic and clinical methods, our child psychiatrist team is weak, and the lack of strict admittance system of professional child psychiatrist. Many autism rehabilitation center established quickly in our country are lack of professional diagnosis and screening system. So the clinical cases not be standardized is the inevitable problems. In fact, the state has promulgated the guidelines for the diagnosis and treatment of autism, more accurate diagnosis and clinical phenotype determination are feasible. The key is to cooperation between basic and clinical research groups, to carry out joint research and development of specialized institutions. The etiological study of ASD is more suitable to research autistic disorder, Asperger's syndrome, childhood disintegrative disorder, and PDD-NOS respectively.

Therefore, precise clinical phenotype, strict classification and diagnosis, to avoid the blindness and repetition of research are imperative. Out of misunderstanding, joint research are direction in future etiological research.

autism spectrum disorder, etiological research, clinical phenotype

doi: $10.1360 / \mathrm{N} 972015-01210$ 